\title{
The Influence of Staff Competency of Integrated Service in Handling of Poverty
}

\author{
$1^{\text {st }}$ Hari Harjanto Setiawan* \\ Research and Development Center of \\ Social Welfare \\ Ministry of Social Affairs \\ Jakarta, Indonesia \\ hari_harjanto@yahoo.com \\ $4^{\text {th }}$ Alit Kurniasari \\ Research and Development Center of \\ Social Welfare \\ Ministry of Social Affairs \\ Jakarta, Indonesia \\ hari_harjanto@yahoo.com
}

\author{
$2^{\text {nd }}$ Setyo Sumarno \\ Research and Development Center of \\ Social Welfare \\ Ministry of Social Affairs \\ Jakarta, Indonesia \\ setyosumarno@rocketmail.com \\ $5^{\text {th }}$ Husmiati Yusuf \\ Research and Development Center of \\ Social Welfare \\ Ministry of Social Affairs \\ Jakarta, Indonesia \\ husmiatiyusuf2005@gmail.com
}

\author{
$3^{\text {rd }}$ Ruaida Murni \\ Research and Development Center of \\ Social Welfare \\ Ministry of Social Affairs \\ Jakarta, Indonesia \\ ruaidamurni@yahoo.co.id \\ $6^{\text {th }}$ Aulia Rahman \\ Research and Development Center of \\ Social Welfare \\ Ministry of Social Affairs \\ Jakarta, Indonesia \\ rahman.aulia12@gmail.com
}

\begin{abstract}
Law No. 11/2009 has stated that the implementation of social welfare carried out by the central and regional government and the community must be directed, sustainable and integrated. The government made a breakthrough in the form of an integrated service and referral system as one of the important instruments in improving the welfare of the poor. The Integrated Service and Referral System (ISRS) according to the Regulation of the Minister of Social Affairs No. 15 of 2018 is a service system that identifies the needs and complaints of the poor and poor people and makes referrals to program managers handling the poor and disadvantaged people at the center and the regions. ISRS in Regency/City began to grow in 2016 after previously conducted research from 2013 under the name "Pandu Gempita". The main objective of this research is to provide input to the government in improving the quality of ISRS services for the poor. The approach used in this study is a mixed method (quantitative and qualitative). The lesson that can be drawn from this study is that the competency of staff has a very high influence in improving services to the poor. Therefore in an effort to improve ISRS services, staff competence must be increased which consists of motivation, attitude, self-concept, science and skills with priority scale that takes into account the results of the research.
\end{abstract}

Keywords-system, referral, integrated, competence

\section{INTRODUCTION}

Services and social problems that have not been optimally sourced from understanding problems that are still sectoral, have not been targeted to the target and are not yet supported. In fact, there are still sectoral service programs found, running independently in accordance with the main tasks and functions of each institution. In Law Number 11 Year 2009 it has been stated that the implementation of social welfare carried out by the government central and regional as well as the community must be directed towards sustainable and integrated [1] The government makes innovation One stop services as one of the instruments to improve the welfare of the population or the poor, especially in aspects of: health, education, and socio-economic, can inspire other regions in the framework of improving the welfare of their citizens according to the characteristics of their respective regions [2] .

One of the Government's efforts to improve the welfare of the poor is to empower and optimize community participation, and ensure the achievement of efficient, effective, fair and sustainable use of resources. Efforts to include the role of the community in the implementation of social welfare is through Integrated of Service and Referral System (ISRS). This system helps to identify the needs of the poor and vulnerable to link with social protection and poverty reduction programs organized by the government (central, provincial, and district/city) according to needs. ISRS also helps identify complaints of the poor and vulnerable, make referrals and monitor complaints handling to ensure that complaints are handled properly. ISRS in Regency or City, is expected to be at the forefront in the field of direct social services, namely the accessibility of social services, social services for referral, social services for advocacy, as well as data and information providers.

The Integrated Service and Referral System (ISRS) according to the Regulation of the Minister of Social Affairs No. 15 of 2018 is a service system that identifies the needs and complaints of the poor and disadvantaged people and makes referrals to program managers handling the poor and disadvantaged people at the central and regional levels [3]. ISRS has become a national priority 
program as mandated in Presidential Regulation number 2 of 2015 concerning the National Medium-Term Development Plan 2015-2019. Carrying out the agenda, requires the involvement of various stakeholders consisting of the Central Government, Local Government, private sector, and the community. One of the main targets listed in the National Medium-Term Development Plan 2015-2019 is to reduce poverty levels to

7.0 - 8.0 percent in 2019 [4]. The percentage of poor people in September 2020 was 9.22 percent or 24.79 million people [5]. Even though the poverty rate dropped from the previous year, it did not meet the targets in the National Medium-Term Development Plan .

The Indonesian Ministry of Social Affairs as the leading sector is obliged to develop ISRS at the district/city level. The implementation of the ISRS was begun in 2013 by the Ministry of Social Affairs through applied research under the name "Pandu Gempita" which stands for Integrated Services of Community Movements in Regencies and Cities. Earthquake Guides are carried out in five districts/cities. The concept was re-developed by National Planing Agency together with Mahkota to develop under the name

"SELARAS". In 2016 it was perfected under the name Integrated of Service and Referral System (ISRS) in 50 Regencies/Cities and Social Welfare Center (SWC) in 100 villages/ village office. Furthermore, in 2017, it will develop more ISRS in 20 regencies/Cities and SWC in 40 villages/ village office. In 2018 develop more ISRS in 60 Regencies/Cities and SWC were developed in 120 villages/ village office. It is expected that in 2019, the number of regions as ISRS organizers will reach 150 Regencies/Cities.

In line with the development of the implementation of the ISRS, which has many benefits for the poor, it has led to initiatives from the local government to develop and organize ISRS independently through regional budget. There are 8 regions that have built ISRS independently, thus the number of ISRS up to 2018 is in 138 city districts. However, in several other regions, there were setbacks in the implementation of ISRS, due to various obstacles. The obstacles faced in each region are quite varied, such as the technical aspects and non-technical aspects; institutional, regulatory and budgeting aspects. The various developments in the implementation of ISRS in several regions have become a separate feature for the Indonesian Ministry of Social Affairs. At the end of 2017, the Directorate of Social Empowerment of Individuals,
Families, and Community Institutions, formed an institution to conduct monitoring and evaluation involving National Planing Agency.

The results of monitoring and evaluation show that, 1) central input in the form of General Guidelines, Provision of Facilities and Infrastructure and Capacity Building Programs has a significant effect in improving the performance of ISRS implementation in the regions. While the implementation of the application system and payment has a negative effect on the implementation of ISRS. 2) in general, beneficiaries in rural villages that have SWC give more positive responses to the implementation of ISRS, compared to areas that do not have SWC. 3) ISRS implementation performance at Regency/City level measured by regulation, Institutional, Budget Support, Data Movement and Complaint Handling, Data Utilization and regional initiatives, obtained in 3 categories (good, moderate or need guidance, lack of or need intensive coaching). The results show that 7 regions in the category are good, 33 regions in the medium category and 5 regions in the category are lacking.

Learning from the results of the monitoring evaluation, refers to the importance of optimizing the reach of beneficiaries of various social protection and poverty reduction programs organized by the government (central, provincial, and district/city) through ISRS and SWC. In addition, it is important to increase the integration of each program organizer, so as to minimize the sectoral ego of institutions/agencies in organizing social problems and/or poverty alleviation programs. In an effort to optimize the delivery of ISRS, it is important to pay attention to the competency factor of officers so that the quality of ISRS services for the poor and vulnerable will increase.

In connection with the research problem, this study will answer how big is the relationship between the competence of officers and integrated services in dealing with poverty.

\section{THEORETICAL FRAMEWORK}

\section{A. Handling of Poverty}

One of the government's efforts to improve the welfare of the poor is to empower and optimize community participation, and to ensure the efficient, effective, equitable and sustainable use of resources. To reduce poverty and income inequality, the government must implement policy strategies that support the welfare of the poor.

The policy is in line with the first objective of the Sustainable Development Goals (SDGs) is that poverty in all forms and dimensions must end with the 
eradication of extreme poverty in 2030 [6]. This is the biggest global challenge and an indispensable requirement for sustainable development. SDGs targets related to poverty, among others, aim at ending extreme poverty for all people wherever they are. By 2030 at least halve the proportion of men, women and children of all ages living in poverty, as well as implementing a national social protection system that applies to everyone, including the poor and vulnerable. Poverty alleviation should not be separated from not being released from the development program in a general way. It is because the root of the problem is not poverty itself. But poverty is a symptom of the disparity in development in various fields that occur between big cities and areas of origin of migrants. The choice to use a strategy that focuses on relief and rehabilitation or is more focused on preventive, mitigation and developmental programs that are multi-sector, multidimensional and multilevel intervention is a choice that must be taken by the government as the bearer of the development mandate, which of course is also assisted by other stakeholders [7].

\section{B. Service Quality}

Service as meeting the needs through other people's activities directly, is a concept that is always actual in various aspects of safety. Not only in business organizations, but has developed more broadly in the order of government organizations [8]. According to Wyckof, service quality is defined as the expected level of excellence and control over the level of excellence to meet customer desires [9]. So, in this study the respondents were beneficiaries of ISRS services.

Based on SERVQUAL theory, the conceptual definition of Service Quality is compiled is a service characteristic that is organized by ISRS which is revealed from tangibles, responsiveness, assurance, empathy and reliability [10]. From this conceptual definition, 5 (five) study dimensions are obtained: (1) Physical appearance dimensions, (2) Responsive dimensions, (3) Assurance dimensions, (4) Empathy dimensions, and (5) Reliability dimensions. The operationalization of the ISRS Service Quality variable is broken down into 5 (five) dimensions and reduced to 11 research indicators.

\section{Officer Competency}

Cohen says that "competencies are the areas of knowledge, abilities and skills that increase and individual's effectiveness in dealing with the world" [11]. Boyatzis said: Competence as a capacity that exists in someone who can make that person able to fulfill what is required by the work in an organization so that the organization is able to achieve the expected results [12]. Shermon says that A competency is an underlaying characteristic of a person, which enables him to deliver superior performance in a given job, role or a situation. This characteristic might be called an "attribute bundle", consist of knowledge, skills, trait, social roles, self-image and motive. The "underlying characteristic", manifests itself in the form of behavior, which helps identification and measurement of competency [13].

Based on the description of the competence theory of Spencer and Spencer's opinion, it shows five dimensions of Officer Competency, as follows: Motives; Traits; Selfconcept; Knowledge; and skills [14]. Then the conceptual definition of variables was compiled that the Officer Competency was the personality and ability of the ISRS executor in carrying out the work. From the conceptual definition it is derived into 5 dimensions of analysis: (1) Dimensions of Motivation; (2) Attitude Dimensions; (3) Dimensions of Self-Concept; (4) Dimensions of Science; and (5) Skills Dimension.

\section{A. Approach}

\section{METHODOLOGY}

The approach used in this study is a quantitative approach (causality and frequency distribution) and to deepen quantitative research results using a Qualitative approach (Mixed Methodology). According to Creswell (1995), the combined methods are:

"A combined method study is one in which the researcher uses multiple methods of data collection and analysis" [15]. While understanding according to Tashakkori and Teddlie is "mixed model studies is somewhat different: These are studies that are products of the pragmatist paradigm and that combine the qualitative and quantitative approaches within different phases of the research process" [16].

\section{B. Population and Sample}

1) Population: The number of ISRS financed by the state budget until 2019 there are 130 districts/cities (in 2016 there were 50, in 2017 there were 20 and in 2018 there were 60). However, the population in this study is ISRS which was established in 2016 and 2017. ISRS which was established in 2018 was not made into a population on the grounds that what was measured in this study is the ISRS service quality that will be asked to beneficiaries, while ISRS which was established in 2018 has not effective because beneficiary data is not yet available. There are two populations in this study, namely ISRS officers and beneficiaries.

The population of ISRS Officers in question are all ISRS officers established in 2016 and 2017 consisting of 1

Manager, 1 Supervisors, 2 front office, 4 back office, 50 facilitator who lead 2 SWC and 2 people in front office of the SWC office 2 people and back office the SWC is 4 people. The total number of ISRS officers is 64 people. Whereas the intended service recipient population is all service recipients who receive services from ISRS as intended in 2018 and until April 2019. Criteria for service recipients are those that have been recorded, identified and referred to in various regional programs, central programs and responsibility programs or corporate social responsibility (CSR).

2) Sample: The attractiveness of the sample in this study uses stratified random sampling. Provinces were 
taken as many as $36.4 \%$ from 22 provinces, namely 8 provinces. The selection of the Provincial sample considers the categories of western, central and eastern regions. The most remote areas in this study include: Aceh, North Sumatra, West Sumatra, South Sumatra, Riau, Riau Islands, Jambi, Bangka Belitung, Lampung, Banten, West Java, Central Java, DIY and East Java. The total number of provinces in the western region is proportionally sampled to be: $14: 22 \times 8=5.1$ so that in the western regions five provinces are taken. Included in the middle region in this study are South Kalimantan, West Kalimantan, East Kalimantan, Bali, and NTB. The total number of provinces in the middle region is proportionally sampled to be: $5: 22 \times 8=1.8$ so that for the central region 2 provinces are taken. Included in the eastern regions in this study are NTT, South Sulawesi and Gorontalo. The total number of provinces in the central region is proportionally sampled to be: $3: 22 \times 8$ $=1.1$ so that for the central region 1 province is taken.

The total population of ISRS officers was $70 \times 64=$ 4,480. According to the Slovin table with a confidence level of $95 \%$, the number of samples was 536. So the number of samples in each district/city was 536: $25=23$, 04 rounded up to 23 . This reserve of 2 respondents, so the total number of respondent officers per ISRS was 25 . Total Beneficiary Population ISRS is $=267,800$ (Source: ISRS National Secretariat). According to the Slovin table with a $95 \%$ confidence level, the number of samples was 599, so the total sample of each district/city was 599: $25=23.96$ rounded up to 24 . Reserves were 1 respondent so that the total Beneficiary respondents for each ISRS was 25.

The selection of respondents was determined by Simple Random Sampling based on a list of service recipients and service personnel obtained from secondary data verified through advance activities (precondition preparation). Randomization in selecting respondents using the online application "Random Number Generator".

In connection with a force majeure, an event that occurs beyond human capability and cannot be avoided so that an activity cannot be carried out as it should. The incident was a forest fire disaster in almost all of Kalimantan. Given these conditions, researchers communicate with the Social Service, which results are no certainty the smoke haze disappears. Based on this information, the two locations on Kalimantan Island were transferred to another area. Regional elections consider the representation of the west, center and east whose proportions have been determined. Because Kalimantan is not possible to be used as a location, the remaining central areas are Denpasar City and Mataram City. So that the number of provinces still remains 8 provinces.

\section{Data Collection and Analysis}

Data collection in research activities is very important because it relates to the availability of data needed to answer problems in research, so that the conclusions drawn are correct. Therefore, in research, data collection methods must be carried out appropriately. In this study using 3 data collection methods, namely: questionnaire, focus group discussion (FGD) and literature study.

Data processing techniques use the computational calculation of the Structural Equation Modeling (SEM) program, which is a statistical computer program that is able to process statistical data precisely and quickly, into a variety of outputs that are desired by decision makers. Data analysis is the processing of data obtained using formulas or with existing rules according to the research approach. Data analysis was performed with the aim of testing the hypothesis in the context of drawing conclusions.

\section{RESULT AND ANALISYS \\ A. Characteristics of Respondents}

In research on the Quality of Services for Integrated of Services and Referral Systems (ISRS) in Indonesia, there are two characteristics of respondents that can be described, namely beneficiaries and officers.

1) Beneficiary: The results of a study with a sample of 625 beneficiaries showed that the majority of the sexes were women, as many as 64 percent. The rest are men as much as 36 percent. Women still dominate the ISRS beneficiaries because most of the men are busy working so that the resolution of household problems is considered as women's business. That should not be the case, men must solve social problems.

The age of beneficiaries is very varied from ages under 25 to over 60 years. But in that age range the most age is the age range between 40 to 44 years which is as much as 16.2 percent. Furthermore, the age range of 35 to 39 years is 15.7 percent. While the least is the age range of 55 to 59 years, which is as much as 5.9 percent. The age range of 15-64 years includes productive age. Productive age is a time when someone is still able to work optimally and can still continue to develop business to meet the needs of personal life and many people. This age has the potential to be developed so that this problem should get the attention of the government because this age can still be developed to be productive.

The level of education needs to be seen because of the assumption that the level of education is correlated with the welfare of a family. The education of the beneficiaries of ISRS services was mostly elementary school educated at 29 percent. Furthermore, graduating from high school was 22.9 percent and graduating from junior high was 21.1 percent. In general, issues regarding education and poverty are almost the same. The linkage of poverty with education is very large because education provides the ability to develop through the mastery of knowledge and skills. Education also instills awareness of the importance of human dignity. Educating and providing knowledge means reaching the future. This should be the spirit to continue making efforts to educate the nation. No exception, justice in obtaining education must be fought for and the government should be at the forefront to make it happen. The poor in the context of social education have links to the efforts of empowerment, participation, 
democratization, and self-confidence, as well as independence.

Most of the work of the head of the family are laborers (washing, building, pelvis, etc.) by 28.2 percent, followed by farmers by 25.6 percent and third not working as much as

20.3. Work and income are very closely related because of the work to get income. The majority of beneficiaries are not earning 20.8 percent. Furthermore, earning Rp.800.000 p to Rp.1.199.000, - by 20.6 percent. The third largest is 18.6 percent, earning Rp.401.000 up to Rp.799.000. Most of the beneficiaries served by the ISRS were included in the BPJS program at 65.8 percent and furthermore it was in the Program Keluarga Harapan $(\mathrm{PKH})$ at 25.4 percent. After that the third is Non-cash food Aid by 17 percent.

2) ISRS Officers: In addition to the beneficiaries, the respondents in this study were ISRS officers consisting of Managers, Supervisors, Facilitators, Front Office (FO), Back Office (BO). This includes the SWC Coordinator, Puskesos Front Ofice (FO), SWC Back Ofice (BO). In addition, there were several regions that added management, including the Health Center Working Group, the education section, secretary, treasurer, and ISRS secretary. The selection of respondents is done through a random system so that all managers have the same rights as respondents.

When viewed by sex, the majority of ISRS officers are men, which is 55 percent. While the female sex is 45 percent. The education of officers is very important and influences the quality of ISRS services. A high level of education is expected to be of high quality of service. Most of the education of ISRS officers is Senior High School, which is

44.2 percent. Next up is graduates S1 / DIV by 42.1 percent, and D3 by 9 percent. The education of many officers is high because it is required and if there is a person who is under high school, it is possible because they come from volunteers. Officers who have higher education will be able to improve their work performance so that the standard expected by the organization is that the quality of ISRS services is also high.

As an ISRS officer, in the category of volunteers who only get a rope and not a salary or salary. However, there are some regions that are responding to supplementing their income from other programs or through other work outside the ISRS. Most of the ISRS officers are non-State Civil Apparatus or contract workers. The possibility of social services is reluctant to involve other workers by providing compassion, so it involves other social pillars. The following diagram is the involvement of officers in social programs. Many ISRS officers are involved in other social programs. The most numerous was their involvement in youth activities, amounting to 26.2 percent. Second is as much as

25.1 percent of PSM. The amount of incentives is mostly between Rp. 260,000 up to Rp. 500,000. The second is less than Rp. 250,000. But there are also those above Rp. $1,000,000-1.9$ percent

\section{B. Results of Causality Relations}

The Staff Competency variable has an influence on the quality of ISRS services by 0.94 . The relationship is very high so to improve the quality of service one must consider factors that influence the competency of

\begin{tabular}{|c|l|c|}
\hline No & \multicolumn{1}{|c|}{ Dimension } & Value \\
\hline 1. & Knowledge & 0,80 \\
\hline 2. & Skill & 0,77 \\
\hline 3. & Self Concept & 0,70 \\
\hline 4. & Trait & 0,51 \\
\hline 5. & Motivation & 0,42 \\
\hline
\end{tabular}

officers.

The competency of officers is the personality and ability of ISRS implementers in carrying out work revealed by Motives, Traits, Self-concepts, Knowledge, and Skills.

TABLE I. VALUE OF INFLUENCE OF OFFICER COMPETENCE ON ISRS SERVICE QUALITY

The table above shows that the competency of officers is formed from 5 dimensions, among others; the dimension of Science (0.80), the Skill dimension of (0.77), the Self Concept dimension (0.70), Traits (0.51) and Motivation (0.42). Factors supporting competency of officers include: a) ISRS officers have all followed technical guidance which is a supporter in ISRS implementation and b) When looking at from the background before becoming ISRS officers are pillars of social welfare that are already active in programs social program. While the inhibiting factors of officer competency include: a) Still found the appointment of ISRS/SWC officers not in accordance with the required criteria and b) There are no competency standards for ISRS/ SWC officers based on workload analysis.

ISRS Service Quality is a service characteristic that is organized by ISRS which is revealed from tangibles, responsiveness, assurance, empathy and reliability.

TABLE II. VALUES THAT INFLUENCE ISRS SERVICES

\begin{tabular}{|c|l|c|}
\hline No & \multicolumn{1}{|c|}{ Dimension } & Value \\
\hline 1. & Reliability & 0,81 \\
\hline 2. & Empaty & 0,79 \\
\hline 3. & Responsive & 0,77 \\
\hline 4. & Assurance & 0,68 \\
\hline 5. & Tangible & 0,56 \\
\hline
\end{tabular}

The table above shows the Quality of Services Installed from the 5 dimensions ordered by priority as follows; First, the dimension must have a value of 0.81 in creating quality service. Second, the dimension of empathy has a value of

0.79 in shaping service quality. Third, responsiveness has a value of 0.77 in shaping service quality variables. The beauty, the dimension of Guarantee has a value of 0.68 in creating quality service. Fifth, physical appearance has a value of 0.56 in shaping service quality variables. 


\section{CONCLUSION}

The competency of the officer has a significant influence on the quality of service. So that the quality of integrated services can be improved through increasing the competency of officers. Based on the value of the priority scale that affects the competency of the officer, it is taken who has a high value above 0.70. To improve the competency of officers can be done through the improvement of Science, Skills, Self-Concept. Increasing the competency of officers can be done through education and training by the Ministry of Social Education and Training Center as a training center or Human Resource Education Center in each region. Consideration for the newly formed ISRS, then in recruiting officers must consider domicile and experience as pillars of social pillars. It is also necessary to formulate the standard of competence of ISRS officers who consider workload proportionally. And competency certification is needed to ISRS officers.

\section{ACKNOWLEDGMENT}

All authors contributed equally to this work. All authors discussed the results and implications and commented on the manuscript at all stages. We thank to Center for Social Welfare Research and Development. This work is supported and funded by Center for Social Welfare Research and Development Ministry of Social Affairs at 2019

\section{REFERENCES}

[1] Undang-undang Nomor 11 Tahun 2009, Kesejahteraan Sosial. Indonesia, 2009

[2] Muhtar and I. Huruswati, "Pelayanan Satu Pintu Penanggulangan Kemiskinan di Kabupaten Sragen," Sosio Konsepsia, vol. 1, pp. 1-25, 2015.

[3] Peraturan Menteri Sosial Nomor 15 tahun 2018, "Sistem Layanan dan Rujukan Terpadu (SLRT)," 2018.

[4] Peraturan Presiden nomor 2 tahun 2015, Rencana Pembangunan Jangka Menengah Nasional (RPJMN) 20152019. Jakarta: Kementerian Perencanaan Pembangunan Nasional/Bapenas, 2015

[5] Badan Pusat Statistik (BPS), "Profil Kemiskinan di Indonesia September 2019," Ber. Resmi Stat., vol. 8, 2020.

[6] Mickael B. Hoelman, B. T. P. Parhusip, S. Eko, S. Bahagijo, and H. Santono, Sustainable Development Goals (SDGs), Panduan Untuk Pemerintah Daerah (Kota dan Kabupaten) dan Pemangku Kepentingan Daerah. INDFID, 2016.

[7] I. R. Adi, "Kemiskinan Multidimensi," J. Makara Sos. Hum., vol. 9, pp. 27-33, 2005.

[8] P. L. Sinambela, Reformasi Pelayanan Publik. Jakarta: PT. Bumi Aksara, 2007.

[9] F. Tjiptono and G. Chandra, Service, Quality dan Satisfaction, 2nd ed. Yogyakarta: Penerbit Andi Yogyakarta, 2007

[10] V. A. Zeithaml, A. Parasuraman, and L. L. Berry, Delivering quality service: balancing customer perceptions and expectations. New York: The Free Press, 2010.

[11] John M. Cohen and S. B. Peterson, Administrative Decentralization (Strategies for Developing Countries). USA Kumarian Press, 1999.

[12] M. Toha, Perilaku Organisasi. Jakarta: Rajawali Press, 1996.

[13] G. Shermon, Competency Based HRM A Strategic for Competency Mapping, Assessment and Development Centres.
Univ Canada Business School: Tata McGraw- Hill Publishing Company Limited, 2004

[14] L. M. Spencer and S. M. Spencer, Competence at Work Models for Superior Performance. United State of America: John Wiley \& Sons, Inc, 1993.

[15] J. W. Creswell, Researh Design Qualitative \& Quantitative Approaches. Thousand oaks london New Delhi: International Educational and Profesional Publisher, 1994.

[16] A. M. Tashakkori and C. B. Teddie, Mixed Merhodology Combining Qualitative and Quantitative Approaches. Sage Publications: International Educational and Professional Publisher, 1998. 